\title{
Behavioral economics perspective on foreign direct investment in emerging markets: The case on Bosnia and Herzegovina
}

\author{
Amra Halaba ${ }^{a^{*}}$, Erkan Ilguen ${ }^{\mathrm{b}}$ and Sanel Halilbegovićc
}

\begin{tabular}{l}
\hline C H R O N I C L E \\
\hline Article history: \\
Received September 5, 2016 \\
Received in revised format \\
September 162016 \\
Accepted October 242016 \\
Available online \\
October 24 2016 \\
\hline Keywords: \\
Behavioral Economics \\
Foreign Direct Investments \\
Emerging Markets \\
Emotional Bias
\end{tabular}

${ }^{a}$ MS in Financial Management, International Burch University, Sarajevo, Bosnia and Herzegovina

${ }^{b}$ Associate Prof. Dr.International Burch University, Sarajevo, Bosnia and Herzegovina ${ }^{c}$ Assistant. Prof. Dr.International Burch University, Sarajevo, Bosnia and Herzegovina

\section{Introduction}

Popularization of studies on FDI started subsequently to the World War Two (Hosseini, 2005), since they increased understanding of how economic agents behave and how economies function in general (Denisia, 2010). Denisia (2010) specifies the following as the main motives for FDI: job opportunities, increased productivity, stronger competition, increase in exports, and access to international capital markets which, according to Moffett et al. (2009), leads to decrease on the cost of capital. Of course, academicians recognize possible drawbacks of the FDI impact on the local markets, as well. Specifically, FDIs create higher competitiveness not only on domestic markets which is beneficial to the certain extent, but also it can lead to shutting down the local companies and to the contraction of the economic development (Denisia, 2010). Many theories offered on the FDI decision making lack one important factor, which is the role of companies' managers in the process of deciding on whether to invest in foreign country, where to invest, and in what way to invest. Psychological findings on 
human nature finally got their role in economic theory and brought the most important insight - thus one that contradicts conventional economic theory - that humans do not behave rationally nor as utility maximizers by default. Managers are not an exempt to this feature (Pinheiro-Alves, 2008).

Through this paper authors aim to point out the major determinants of FDI from perspective of BE. Pinheiro-Alves (2008) supported the statement of Katona (1975) that every decision related to FDI involves two basic elements: "economically rational" (p.5) and "behavioral" (p.5) ones. So, author considers the basic behavioral rules that may have impact on the decisions regarding FDI and that may cause deviation from utility maximization function. Pinheiro-Alves (2008) points out that economists need to assess process of making decisions regarding FDI, while "a better understanding of how decisions are made will lead to better predictions concerning which alternatives are chosen" (Bernheim, 2009 , p. 116). It is plausible to analyze FDI from this perspective in emerging markets, especially when it comes to B\&H due to its specific social and economic situation. Despite the complex post-war state organization and the fact that it accommodates multiethnic structure of people and their fresh wounds and inside conflicts, B\&H started its economic recovery. So, one of the goals for Bosnian economic revival is to attract FDIs due to its implied contribution to the economic growth and development (Ilgün \& Coşkun, 2009). The main objective is to investigate what drives FDIs in nations that are progressing toward more developed economies, specifically on the example of Bosnian rather non-favorable business environment. Therefore, authors argue that such an environment creates fruitful ground for irrational motivations in investing, so that in absence of rational incentives investment decisions are based on the feelings and confidence of investors rather than e.g. on Return on Investment (ROI) and profit margins.

\subsection{Theory of Foreign Direct Investment}

According to Denisia (2010) one basic remark on the theory of FDI is set initially by Kindleberger (1969), who said that FDI would not exist if there were perfect competition in the world, efficient markets and no trade barriers. Market has to experience some kind of distortion in order to allow for FDI and generate positive results. Denisia (2010) summarizes basic theories on FDI and concludes that any of the existing theories on FDI would not provide its full explanation. Ricardo's comparative theory, as the first attempt to explain the FDI, failed because this model includes two countries between which capital is perfectly mobile. In such situation FDI would not be possible because one of the basics for investing abroad is that one country has an advantage over another. Another interpretation offered was under portfolio theory, which is not suitable due to the fact that it only looks at investments which are part of portfolio but not the direct investments (Denisia, 2010; Hosseini, 2005). Additionally, Hosseini (2005) criticizes portfolio theory because it assumes the environment without uncertainty and risk, which is far from the real situation. Mundell's model was another failing attempt at interpreting the FDI, since it was applicable only on investment of narrower time frame and capital needed than for direct investments. (Denisia, 2010; Mundell, 1957).

Vernon's production cycle theory tries to explain direct investments made by US investors in Europe mainly, by firstly introducing four cycles of production: innovation, growth, maturity, and decline. In the period before the World War Two, US companies were innovating new products and therefore had a technological advantage over European companies. After the war Europeans demanded more US products and export increased. However, when US products reached maturity phase Europeans already were able to copy their inventions, started their own production, and demanded less US products. To fight the new competition, US companies started investing directly in European countries and producing there. What this theory does not explain is the notion that US companies also had invested directly even in those areas in which they were not technologically more advanced than Europeans (Denisia, 2010; Vernon, 1966) 
Another theory which aims to explain FDI is based on notion of capital market imperfections and uncertainty factor. Empirical analysis showed that higher real exchange rate causes higher FDI made by US dollar and appreciation of US dollar causes lower FDI made by US. The lack of this theory is that it cannot explain movements of FDI made by two or more countries - that is two or more currencies - at the same time (Cushman, 1985; Denisia, 2010). Internationalization theory explains FDI on the basis of advantages which specific companies attain internally and then use as competitive tool abroad (Buckley \& Casson, 1976; Denisia, 2010). FDI is sustainable only when company's internal advantages are higher than costs of doing business in foreign countries. Also very important note is that FDI is decision which results from company's strategy rather than from capital market conditions (Denisia, 2010; Hymer, 1976). Hymer's study was based on the assumption that FDIs arise as result of market imperfections. His reasoning behind this claim is that companies which decide to invest abroad have to have some advantages over local companies due to certain imperfections of the market, because naturally local companies are expected to have beneficial position over the foreign ones due to the cost of operating abroad. These market imperfections are reflected in technology development, product quality, and economies of scale (Hosseini, 2005; Hymer, 1976).

OLI paradigm or eclectic theory of FDI considers three factors and states that these factors are unique for each company depending on its business strategy and eventual compatibility of strategy with certain country's economic, political, and social conditions. Factors assessed stand for abbreviation OLI and are the following: O - ownership advantages, L - location advantages, I - internationalization. Ownership advantages include monopoly rights, technology advantages, and economies of large size. It is necessary that these factors make it cost or income beneficial for a company in order to invest abroad. If company finds that it can either decrease its costs or increase its earnings by exploiting these factors in foreign country, than it looks for the best suiting location. Location choice depends on economic, political, and social benefits of specific countries. In case that the company possesses the ownership advantages which can be benefited in foreign county, then it looks for whether it is more beneficial to invest directly in foreign country rather than enter foreign market through some other form of business agreement. This is referred to as internalization factor. (Denisia, 2010; Dunning, 1988)

Hossein (2005) notes that some modern theories on FDI are based on some more realistic factors and cites Markusen (1995) who says that "trade and gains from trade can arise independently of any pattern of comparative advantage (as traditionally assumed) as firms exploit economies of scale and pursue strategies of product differentiation in an imperfectly competitive environment' (p.169)" (Hosseini, 2005 , p. 530). However, he claims that even these theories do not provide complete interpretation of FDI.

\subsubsection{Foreign Direct Investment in Bosnia and Herzegovina}

Ilgün and Coşkun (2009) present findings on development and growth opportunities of FDI in B\&H. They refer to the study of Serin et al. (2008) who recognized that there was a rising interest of foreign investors in countries of South-East Europe (SEE) including B\&H. They attributed growing interest of investors to easier access to markets of these countries. Furthermore, Ilgün and Coşkun (2009) note that B\&H is indeed experiencing a "strong post-war recovery" (p. 52). They present some fundamental economic indicators, such as GDP and GDP per capita, and emphasise that B\&H brought inflation rate to the level of EU and that strength of domestic currency grew significantly since it was pegged to Euro. On the other hand, they point that still B\&H faces major trade deficit and it still enjoys status of mainly importing country. They refer to Škuflić and Botrić (2006) who recognized the two most significant factors with regard to FDI into B\&H. These are political stability and investors' protection. Ilgün and Coşkun (2009) point at another very important factor, which is the time and monetary costs of setting business in the country. With regard to attraction of FDI, Bosnian government makes certain efforts. For example, it introduced the Law on Foreign Direct Investment according to which foreign investors enjoy certain reliefs when starting business in B\&H. Santander Trade Portal (STP) (2014) 
summarizes the main governmental activities targeted for attraction of FDI to the introduction of: State Foreign Investment Policy Law, support fund for foreign investors, homogenous trade and customs policy, homogenous treatment for both domestic and foreign investors, prohibition for expropriation or property.

According to report of Foreign Investment Promotion Agency (FIPA) in B\&H published in 2014, FDI in $\mathrm{B} \& \mathrm{H}$ is experiencing the trend that goes along with global FDI trends. FIPA reports that B\&H encountered the biggest inflow of FDI just before the start of global financial crisis in the year 2007 (when FDI amounted to EUR 1.3 billion), but this amount decreased due to consequences from the crisis. Despite decrease in FDI inflow in the post-crisis period, they report as an encouraging sign the fact that B\&H attracted Greenfield investments and investments in production immediately in 2008 . Relatively soon after crisis, from 2010 FDI inflows start experiencing upward trends.

According to announcements of Central Bank of B\&H, FIPA (2014) reports that the biggest share of FDI inflows in $\mathrm{B} \& \mathrm{H}$ was directed to production sector, followed with banking sector, telecommunication, trade, real estate, service, other financial service, tourism, and transport. Countries that invest the most in B\&H are in the first place Austria, followed by neighbourhood countries Serbia, Croatia, and Slovenia.

STP (2014) specifies lack of transparency of procedures and poor legal framework for businesses as two main aggravating circumstances for investing in $\mathrm{B} \& \mathrm{H}$.

In order to provide intuition about situation on FDI in B\&H authors of this research provide briefing from report made by this portal which presents Bosnian world rating along several dimensions concerning investors' protection and include ratings for US as a comparison measure. Transparency index (where higher index implies higher transparency) for B\&H is 3.0 compared to index of US of 7.0. Index of manager's responsibility (higher index shows that manager is more personally responsible) for B\&H is 6.0 compared to US' 9.0. Index of shareholder's power (higher index indicates easier procedures for shareholder to undertake legal actions) for $\mathrm{B} \& \mathrm{H}$ is 6.0 compared to US' 5.0.

\subsection{Theory of Behavioral Economics}

Mainstream economics upholds that people make decisions based on utility maximization function that is by outweighing the pros and cons of each available option and choosing the one that provides the highest benefits with minimum costs and thus contributing to their overall wealth. It is assumed that economic agents are perfectly rational and any emotional influences are out of consideration. Such subtle but essential elements, such as emotions and human's intuitions are being excluded from traditional economics models. Moreover, such view is considered relevant even for decision making situations that involve risk and uncertainty (Jarboui \& Boujelbene, 2012).

According to Hadžić (2015) "human mind is not only "algorithmic" in its nature, but much more alike of "quantum machine" in which one of the main properties is uncertainty. This metaphor suggests that humans do not act all time in the most sincere way, thus quantitative approach alone might not be the most accurate in such case." (p. 58). Furthermore, Hadžić (2015) proposes that environments which score high on uncertainty are the ones where analysis-based decision making is condemned to fail. Such environment, according to him, asks for intuitive decision making. Decisions regarding FDIs are exposed to enormous amount of uncertainties and intuitive approach to judgment and decision making is in direct confrontation to standard economics postulates. Another important determinant of markets according to standard economics is called the efficient market hypothesis. In short, it is assumption that all prices on the market reflect the actual value of the assets (Barberis \& Thaler, 2003). Rational model of economic theory tried to put together all the pieces of the economy's structure into a fine tuned theory based on the rational expectations (Shiller, 2003). However, due to unpredicted movements, especially when it comes to stock market prices, this approach is questioned and enriched by insights 
from psychology, sociology, demography, history, and most of all from emerging field of behavioral finance (Shiller, 2000).

The exclusion of intrinsic human components from economic models, can be explained by concern of not making a good decision when relying on those. However, a person cannot detach oneself from those inborn components. For this reason, researchers have come to incorporate findings from psychology and neurobiology into studies of investment decision making (Pham, Lee, \& Stephen, 2012). Furthermore, Jarboui and Boujelbene (2012) argue that emotions were not included in traditional economic models due to the fact that they are complicated to analyze, impossible to control and do not pertain for long time periods. But despite this, economists recognized the importance of adding the intuitive processes of making choices to the traditional ones. Only in this way we can have a full apprehension of economic agent's behavior.

Hadžić (2015) refers to Kahneman's (2011) conclusion that strong impact on human decision making in general has a context, that is framing of decision environment and emphasizes his remark that the same situation framed (presented) differently activates different emotions with decision maker.

One of the arguments of behavioral economists is that individuals do not behave rationally, exactly due to the lack of information and ability to interpret the available information correctly (Jarboui \& Boujelbene, 2012). This is referred to as "bounded rationality" and it is ground basis for behavioral economics' research (Deffains \& Ferrey, 2007). Furthermore, people often face time constraints, which do not allow them to search for enough material, nor to dedicate some time to think about alternatives. Rather they are forced to make decisions instantaneously (Jarboui \& Boujelbene, 2012). One can argue that even in such pressure situations "rational economic agents" are able to stay cold-minded and perform the utility analysis of choices. However, Shull (2013) sets forth the findings from recent neuroeconomics studies which show that humans have ability to make only two consequent deliberate decisions.

\subsection{Behavioral Economics Approach to Foreign Direct Investment}

Hosseini (2005) argues that all theories on FDI which arose after the World War Two are inferior to behavioral economics approach which he took even though he acknowledges their contributions. Also, Hosseini (2005) reminds on trend of looking out of economics research scope when investigating the FDI decisions and finds it important that we can stay in the area of economics by using behavioral economics' findings in explaining how companies make decisions regarding direct investments abroad. According to Hosseini (2005) economics need to include realistic principles in order to explain FDI, and exactly behavioral economics looks at how economic agents really behave in real surrounding (Baker \& Nofsinger, 2002; Thaler, 1993).

When a company's management makes decision to invest in foreign countries and to which country to invest in, the difference between revenue and costs is what should be their guidance according to standard economic theory and, of course their aim is to invest in the option which offers the maximum possible difference between revenue and costs. On the other side, behavioral economics takes into consideration personal traits of specific managers and looks into how these influence managerial decision making. More importantly, deciding on FDI takes more than one person, who then all together influence the final decision either directly or indirectly (Pinheiro-Alves, 2008).

Whether to invest and where to invest depends on managers' expectations on future values of revenues, costs, interest rates, inflation, aimed rate of return, and assumed risk of investment. These variables are used to derive net present value of investment. These expectations are dependent on subjective values, beliefs, and perceptions of individual managers or investors (Pinheiro-Alves, 2008). Traditional economics did ignore human (instinctive) nature in its models, but incorporation of these real factors 
is not something new. It was actually revealed a long time ago, by one of the most influential economists John Maynard Keynes. He suggested that people are driven by inner animal spirits in their economic behavior. Animal spirits take into account "confidence, trust, mood, and expectations" which are all components of investor sentiment. (Riley, 2012) In his analysis of the animal spirits - which was initially proposed by (Keynes, 1973) and later elaborated by many academicians - Schwartz (2010) supports interpretation offered by Koppl (1991). Specifically, Koppl suggested that those animal spirits can induce rational activities at times. (Koppl, 1991; Schwartz, 2010)

\subsubsection{Enviroment of Decision Making on Foreign Direct Investment}

Hosseini (2005) argues that traditional economics lacks capacity to address the environment met by companies that invest directly in foreign countries. Companies that go abroad for doing business face new economic, political, social, and cultural circumstances. Very important notion is that doing business abroad means higher uncertainty and therefore higher risk for companies. According to Barberis and Thaler (2003), people do not like being uncertain and this dislike for market uncertainty - that is market ambiguity is called ambiguity aversion. According to Shull (2013) the ambiguity of the market is the reason number one of difficulties in making investing decisions. People have inborn tendency to search for certainty, safety, and reliability. However, the market and price movements are anything but certain. So when it comes to making a decision in such circumstances inevitably there will be different "conflicting answers" to questions that naturally arise in the market.

Pinheiro-Alves (2008) refers to Aharoni (1999) who recognized that specifics of any FDI decision are: a lot of data needed, many small decisions to be made in different time periods over the months or years, and investments needed to be made on long-term basis.

One of special concerns is also information asymmetry that foreign investors face, where we need to consider the role of media. Kahneman (2011) says that media likes reporting on what is new and hot. Sewell (2011) additionally says that media reports on unusual and surprising events more severely than on more common ones, and continues with notion that media generates "biased impression of the world around us" (p.4). Also, very important feature of the media is that they create news based on what the public wants to hear Kahneman (2011). This is quite troublesome, since Daniel, Hirshleifer and Teoh (2002) conclude based on the relevant research that price formation, which than leads the market conditions, is by far influenced with the way in which information are given in the public. Hosseini (2005) argues that any newly attained information is of subjective influence for each individual manager or investor, because of different perception and processing abilities they possess, so also each company will react in unique way to any new piece information. Also, he points that more complex information are more managers become prone to committing mistakes.

Hosseini (2005) notes that companies that go abroad for investing have many decisions to make, regarding location, supply chain, distribution network - which are far more complicated when compared to doing business locally. As factors in all these decisions, Hosseini (2005) emphasizes importance of cultural apprehension, specifically language, religion, ethnicity. Pinheiro-Alves (2008) identifies the very first attempt to explain the FDI related decisions made by companies from behavioral perspective was one given by Johanson and Vahlne (1977) who used the psychic distance to assess the decision as to where to invest. So, they defined the psychic distance as "the sum of factors preventing the flow of information from and to the market. Examples are differences in language, education, business practices, culture and industrial development" (Johanson \& Vahlne, 1977, p. 24; PinheiroAlves, 2008, p. 4)

Hosseini (2005) refers to Aharoni (1966) who pointed at importance of political uncertainty in making decision as to whether invest abroad and in which form. According to him political situation is far more important than costs that company would face, because political situation can suddenly change while 
costs usually change slowly and more subtly. Hosseini (2005) claims that managers may misinterpret certain political events which simply do not align with their previously established beliefs, which is recognized as representativeness heuristic by Kahneman (2011) who describes humans as "pattern seekers", meaning that people are always looking for relation between certain events. It is in human nature to look for how any new events that happen fit into existing schemes. People believe that everything occurs according to the plan. This may be because of the need to have things under control, so when unexpected things happen people provide them with certain justification. Human brain is inclined to classify things that have few common characteristics as equivalent (Baker \& Nofsinger, 2002). Furthermore, Hosseini (2005) claims that managers of companies usually overreact to those "discontinuous, recent and emotionally charged events" (p. 536) while overlooking the "continuous and more permanent political events" (p. 536). This phenomenon arises due to availability heuristic and affect heuristic.

According to Kahneman (2011) the basic premise of the availability heuristic is that humans make inferences by using those data that are most easily accessed at the specific point of time. Such practice triggers attention especially when we take into account that the most available and prominent information comes from media. Pinheiro-Alves (2008) provides an example of how availability of media news influenced Portuguese government to invest in Brazilian market. In the year 2000 primeminister of Portugal visited Brazil on few occasions and publicly gave speeches in which he directly tried to persuade investors to make investments in the Brazilian market. Additionally, the same year was labelled with the 500th anniversary of Pedro Alvares Cabral discovery of Brazil, so this very important event for both countries had great media coverage. Portuguese investors were influenced by the news exposed in the media which kept their interest away from the other potential investments. When it comes to affect heuristic the basic idea behind it according to Kahneman (2011) is that people's emotions are leading force in their judgment of risk preference. He emphasizes that it was established by Paul Slovic, who proposed that people assess the risk of certain objects by answering themselves questions about how they feel about them personally. Every decision people make is pure reflection of their emotions, regardless of whether they intentionally employ their emotions or not. Finucane et al. (2000) argue that affect heuristic drives risk perception. They demonstrate that when people like certain thing they evaluate it as less risky and if they do not like something then they evaluate it as more risky. There is evidence, that investors do not consider too much information which is undesirable for them at some moment, but on the other hand put too much importance on desirable information (Daniel et al., 2002; Easterwood \& Nutt, 1999). Ariely (2008) suggests that emotions drive people behavior. He conducted experiments which showed that people under emotional arousal engage in behaviors that they could never think of. According to Pinheiro-Alves (2008) the most important determiner of environment in which FDI related decisions are to be made is uncertainty. If everything would be known the only analysis to be conducted would be comparison of the expected revenues and costs. However, since this is not the case, managers face a far more complex circumstances. Uncertainty is defined as "the absence of ability to decipher all of the complexity of the environment; especially one whose very structure itself evolves over time" (Heiner, 1983, p. 569; Pinheiro-Alves, 2008, p. 4). Pinheiro-Alves therefore states that behavioral approach to FDI decisions looks at cognitive characteristics of managers who act in environment of uncertainty.

\subsubsection{Psychology in Managerial Decision Making}

People are equipped with an inborn laziness and are prone to simplify any questions that come to their way (Kahneman, 2011). Those simplifications of reality are called heuristics - that is substitution of some difficult questions for some more simple ones that are easier to answer to. These simpler questions are actually intuitively retrieved from the memory just based on whether they in certain way relate to what is already in person's memory. Such process falls on behalf of intuitive system of thinking, whose main characteristics are effortless and unintentional judgments. People are likely to rely on heuristic simplifications when they have to deal with some complex issues (Kahneman, 2011). Heuristics are 
those anomalies in human behavior which come up sequentially led by intuitive thinking and result in predictable biases. These deviations from rational behavior may be disciplined. The problem is that the point in which person comes to realizing his or her own biased behavior is usually the one in which the environment has already significantly changed and demands a new approach, so that learning of one's own behaviors has to start over. The task of behavioral economics, therefore is to recognize those persistent deviations from rational behavior by managers and companies which persist even despite learning and incentives (Pinheiro-Alves, 2008).

Kahneman and Riepe (1998) argue that rational agents make investment decisions based on the final point where they want to get. The main goal of the rational investor is to derive maximum utility from the investment. Therefore, if an investor instead on the final goal focuses on temporal variations - that is "goals and losses"- on his or her way to that goal, we can call such investor as irrational one. What causes irrational behavior, and as we can see unbeneficial also, is failing under the flaw of emotions. These are emotions that are woken up by "gains and losses", but in reality are not directly related to those variations. Nevertheless, changes in behavior due to emotions arose, no matter how irrelevant they are, cause investors to take their mind of the final point they want to achieve, which is maximizing their earnings.

Kahneman (2011) makes resume of the basic human characteristics that determine their behavior. In principal, individuals think and behave rationally and those exempt situations in which their rationality vanishes are due to emotions that take them over in specific situations. Furthermore, Kahenman (2011) propounds how certain pop-ups (such as thoughts, emotions, or memories) in people's "working memory" (p. 38) distort their cognitive functions. Exactly possibility of depletion of human's "cognitive resources, such as time, memory, and attention" is considered ground for making wrong judgments and biased decisions. (Daniel et al., 2002, p. 143).

General determinant of human behavior is that people faced with specific circumstances will retrieve stored memories and experiences related to their present condition and through cognitive processes create so-called "mental scenarios". Once the "scenario" is created they asses the possibility of "scenario's" actual realization. Pham, Lee and Stephen (2012) More contemporary view is that human behavior is actually led by emotions present at the specific situation (Bechara et al., 1997; Phamm et al., 2012; Slovic et al., 2002)

Kahneman (2011) gives a good explanation of how humans have two separate, but still overlapping systems of thinking, "System 1" which is an intuitive one and operates on subconscious level and "System 2" which is a rational one and operates on the conscious level. Intuitive thinking is always active. All the time, while awake, human brain unintentionally observes the surrounding, receives new data, retrieves the related existing data from working memory, and makes "computations" based on the combinations of these. Often times, people put weight on things observed based on how easy they can be retrieved from the memory. These are processes that occur without person's awareness. On the other side, rational thinking occurs intentionally and is active only when person needs it or wants it. In this case, assessment of the observed stimulus occurs intentionally and consciously. But, paradoxically, this thinking does not produce accurate judgments every time.

Managers and investors who decide on company's activities and eventually FDIs have different mental processing capabilities and different perceptions of the reality Hosseini (2005). People make judgments in the context of the meaning it has for them. When people consider specific issues, they consider that issues from the angle that feels accordant with their preferences (Rabin, 1998). Kahneman (2011) argues that human tendency to frame the choices and decision processes presents the basic challenge to rationality assumption of the standard economics. The same information presented in two different ways will lead to different judgments, since the way of representation causes certain emotional reactions. Hosseini (2005) referring to his work from 1994 concludes that "while the complexity of 
the international environment faced by decision makers is unlimited, decision makers have limited capacity for facing this complexity" (p. 536).

\section{Materials and Methods}

The goal of the study is to investigate how decisions regarding FDI are made in B\&H with specific respect to its non-favorable social and business environment. For this reason, the focus is put on variables offered in branch of behavioral economics along with certain fundamental variables that consider also. Behavioral economics allows for deviations from rationality of economic agents and deviations from utility maximization function by providing suitable evidence from studies on psychology and neurology of investors and/or managers.

Tested hypothesis are the following:

Ha1: Amount of FDI to B\&H increases when managers of companies make decisions based on irrational factors.

Ho1: Amount of FDI to B\&H does not increase when managers of companies make decisions based on irrational motivations.

Ha2: Amount of FDI to B\&H does not increase when managers of companies make decisions based on rational factors.

Ho2: Amount of FDI to B\&H increase when managers of companies make decisions based on rational factors.

In order to test these hypotheses, authors examine the contribution of two sets of factors on amount of FDI.

Specifically, these sets refer to irrational and rational ones.

Irrational factors include: business instinct, previous experience in the same industry, implying anchoring heuristic, visibility of investment in local community, implying availability heuristic, acquisition of reputable brand, implying representativeness heuristic, and preventing competitors to acquire the market, implying greed, which arises from affect heuristic.

Rational factors include: reducing dependence from suppliers, acquiring new technology, upgrade in value chain, and feasibility analysis done by third, reputable party.

For the purpose of this research authors use questionnaire, asking about companies' motivations for direct investments in B\&H. It consists of eight questions. First question asks for basic data about company, followed by questions about ownership and organizational structure, industry, turnover, and growth strategies. Next question asks about ten different motivators for direct investment in general and the last query refers to the business environment of B\&H.

Choice of methodology for analysis was limited to the large extent by the number of responses to the survey. The sample size consists of 44 responses, so correlation and regression analysis are used for testing hypothesis. Furthermore, these analysis are found to be the best measures of impact that certain determinants (rational and irrational) have on investment decision. Specifically, in questions 7 and 8 the range of rational, irrational and neutral positions is identified to enable analysis of different determinants. In certain areas where correlation and regression are not applicable to explain some patterns and links, observation is used to measure relative influence of rational and irrational reasons on investment decision. Additionally, theoretical background and recent reviewed in prior sections is related to the results of primary research, by using desktop analysis as well as comparative analysis whenever applicable. 
It is important to note that respondents did not answer to all questions contained in the questionnaire. However, those missing values are not found as distortive of results' reliability.

Survey questions generated 23 variables, which are coded as follows: "V1" stands for number of years that company operates in B\&H; "V2" stands for number of owners that hold majority of the company (how many owners hold more than 50\% of shares); "V3" stands for average annual DI (direct investment) by company to B\&H; "V4" stands for origin of investor; "V5" indicates whether company is part of large business group or not; "V6" stands for industry sector in which company operates; "V7" stands for average annual turnover of the company; "V8" indicates which other growth strategies except FDI does company use; "V9" indicates how much company relies on business instinct in making FDI decisions; "V10" indicates how much company relies on previous experience in industry while making FDI decisions; "V11" indicates how much company is affected by visibility of investment option in making FDI decision; "V12" indicates how important for company is possibility of brand acquisition in making FDI decision; "V13" indicates how important for company is to prevent competition of entering certain market while making FDI decision; "V14" indicates how important is reduced dependence on suppliers as factor in making FDI decision; "V15" indicates how important acquisition of new technology is in making FDI decision; "V16" indicates how important for company is upgrade in supply chain while making FDI decision; "V17" indicates how important is Return on Investment (ROI) is for company while making FDI decision; "V18" indicates how much company relies on feasibility analysis done by a third party when making FDI decision; "V19" shows to what extent complexity of B\&H's business environment prevents companies to invest to B\&H; "V20" shows how seriously companies consider to retrieve their investments from B\&H due to complex business environment; "V21" indicates to what extent present foreign companies in B\&H discourage other companies to invest in $\mathrm{B} \& \mathrm{H}$; "V22" indicates to what extent foreign companies invest to B\&H only due to high returns; "V23" shows how qualified B\&H's workforce is perceived by present foreign companies.

In the next section analysis of responses is performed along these variables utilizing correlation and regression analysis.

\section{Results}

The first hypothesis that amount of investments increase when managers rely on irrational factors while making FDI decisions is tested by linear multiple regression by enter method and excluding cases list wise. Dependent variable is the average annual amount of FDI to B\&H by companies in three years prior to date (V3). Independent variables are irrational factors which lead companies to invest in B\&H - that is those factors except Return on Investment (ROI) and profit margins. These include the variables business instinct V9, V10, V11, V12, V13, which are defined in the section 4.

Table 1

Model summary - Irrational predictors

\begin{tabular}{|c|c|c|c|c|c|c|c|c|c|c|}
\hline \multirow{2}{*}{ Model } & \multirow[b]{2}{*}{$\mathrm{R}$} & \multirow[b]{2}{*}{ R Square } & \multirow[b]{2}{*}{$\begin{array}{l}\text { Adjusted } \\
\text { R Square }\end{array}$} & \multirow[b]{2}{*}{$\begin{array}{l}\text { Std.Error of } \\
\text { the Estimate }\end{array}$} & \multicolumn{5}{|c|}{ Change Statistics } & \multirow[b]{2}{*}{$\begin{array}{l}\text { Durbin- } \\
\text { Watson }\end{array}$} \\
\hline & & & & & $\begin{array}{l}\text { R Square } \\
\text { Change }\end{array}$ & F Change & df1 & $\mathrm{df} 2$ & $\begin{array}{l}\text { Sig F } \\
\text { Change }\end{array}$ & \\
\hline 1 & ,394 & 155 & ,014 & 1,652 &, 155 & 1,103 & 5 & 30 &, 380 & 1,983 \\
\hline
\end{tabular}

Table 1 shows summary of regression model. R square amounts to 0.155 and indicates that predictive power of the model is $15.5 \%$. Model's strength is poor, but adjusted $\mathrm{R}$ square is lower than $\mathrm{R}$ square, so there is no need for introduction of other factors to explain the changes in dependent variable. Durbin Watson statistic is 1.983 , which is close to value of 2 and indicates that there is no autocorrelation. Table 2 provides Collinearity Statistics. Tolerance level for all variables is greater than 0.10 and that VIF level for all variables is lower than 10 , meaning that multi-collinearity is not a problem. 
Table 2

Coefficients in the model with irrational predictors

\begin{tabular}{|c|c|c|c|c|c|c|c|c|}
\hline \multicolumn{2}{|c|}{ Model } & \multicolumn{2}{|c|}{$\begin{array}{l}\text { Unstandardized } \\
\text { Coefficients }\end{array}$} & \multirow{2}{*}{$\begin{array}{c}\text { Standardized } \\
\text { Coefficients } \\
\text { Beta }\end{array}$} & \multirow[b]{2}{*}{$\mathrm{t}$} & \multirow[b]{2}{*}{ Sig. } & \multicolumn{2}{|c|}{ Collinearity Statistics } \\
\hline & & $\mathrm{B}$ & Std. Error & & & & Tolerance & VIF \\
\hline \multirow[t]{6}{*}{1} & (Constant) &,- 151 & 2,285 & &,- 066 & ,948 & & \\
\hline & $\begin{array}{l}\text { Business instinct as factor in FDI decision } \\
\text { making }\end{array}$ & ,387 & ,348 & ,248 & 1,111 & ,276 &, 567 & 1,765 \\
\hline & $\begin{array}{l}\text { Previous experience in the same industry as } \\
\text { factor in FDI decision making }\end{array}$ &, 141 &, 514 &, 054 & ,275 & ,785 & ,738 & 1,356 \\
\hline & $\begin{array}{l}\text { Visibility of investment in local community as } \\
\text { factor in FDI decision making }\end{array}$ &,- 189 & ,282 &,- 146 &,- 671 &, 507 &, 597 & 1,676 \\
\hline & $\begin{array}{l}\text { Acquisition of reputable brand as a factor in FDI } \\
\text { decision making }\end{array}$ & , 120 & ,268 & 099 & ,446 & 658 & ,575 & 1,740 \\
\hline & $\begin{array}{l}\text { Preventing competitors to acquire market as } \\
\text { factor in FDI decision making }\end{array}$ & ,259 & ,256 & 199 & 1,012 & 320 & ,728 & 1,373 \\
\hline
\end{tabular}

Further indicator from the Table 2 are coefficients assigned to each independent variable and respective significance values. Significance values for all independent variables are higher than 0.05 level of significance, which indicates that none of these variables is statistically significant at 0.05 significance level in prediction of dependent variable. Authors decide to be cautious and do not rigorously dismiss the analysis results, since such results are very likely to be due to moderate sample size. Rather, authors find it plausible to use the predictors for equation building, while noting that this analysis should be repeated with higher sample size and over longer time period. In that way it would possible to compare currently obtained results with future ones, examine predictive power of the model, and work towards establishment of better predictive model of motivations for FDI to B\&H.

So, predictors are to be analysed in context of their contribution to prediction of average annual amount that foreign companies invest directly in $\mathrm{B} \& \mathrm{H}$. To create the regression model, unstandardized coefficients are used. The model is presented in the Eq. (1), given below. It shows contribution that predictor variables (factors involved in FDI decision making considered from perspective of behavioural economics) have on average annual amount that company invests in foreign market. Four out of five considered factors predict higher annual amount of DI in B\&H, except for the visibility of investment in local community. When decision makers rely on visibility of investment in local community as factor in making decision regarding DI to B\&H, the amount of investment decreases. In case that decision makers rely on remaining four factors, investment amount increases. Additionally, business instinct is mostly cause of higher investment amount, with coefficient of 0.387 . Following the business instinct, there are desire to prevent competitors to enter a market with coefficient of 0.259 , previous experience in industry with coefficient of 0.141 , and acquisition of reputable brand with coefficient of 0.120 , as factors which lead to higher investment amount.

Average Annual Amount of DI by Company in last 3 years

$=$

$-0.151+0.387$ (Businessinstinct)

+0.141 (Previousexperienceinthesameindustry)

$+(-0.189)$ (Visibilityofinvestmentinlocalcommunity)

+0.120 (Acquisitionofreputablebrand)

+ 0.259 (Preventing competitorstoasquiremarket

The second hypothesis that amount of investments increase when managers rely on rational factors while making FDI decisions is also tested by linear multiple regression by enter method and excluding cases list wise. Dependent variable is again average annual amount of direct investment made by company in last 3 years (V3). Predictor variables are reducing V14, V15, V16, V17, V1, which are defined in the section 4 . 
Table 3

Model Summary - Rational Predictors

\begin{tabular}{|c|c|c|c|c|c|c|c|c|c|c|}
\hline \multirow[t]{2}{*}{ Model } & \multirow[b]{2}{*}{$\mathrm{R}$} & \multirow[b]{2}{*}{ R Square } & \multirow[b]{2}{*}{$\begin{array}{l}\text { Adjusted } \\
\text { R Square }\end{array}$} & \multirow[b]{2}{*}{$\begin{array}{l}\text { Std.Error of } \\
\text { the Estimate }\end{array}$} & \multicolumn{5}{|c|}{ Change Statistics } & \multirow[b]{2}{*}{$\begin{array}{l}\text { Durbin- } \\
\text { Watson }\end{array}$} \\
\hline & & & & & $\begin{array}{l}\text { R Square } \\
\text { Change }\end{array}$ & F Change & df1 & df 2 & $\begin{array}{l}\text { Sig F } \\
\text { Change }\end{array}$ & \\
\hline 1 & ,403 &, 162 &, 027 & 1,591 &, 162 & 1,201 & 5 & 31 &, 332 & 2,205 \\
\hline
\end{tabular}

Table 3 shows summary of regression model, where the focus is put at R square and adjusted R square values to check the strength of the model. $\mathrm{R}$ square is 0.162 which indicates weak to mild predictive strengths of the model with $16.2 \%$ of dependent variable explained with predictors. Adjusted R square is lower than R square, meaning that there is no need for additional predictors to be included in model. Durbin-Watson statistic with value of 2.205 indicates no autocorrelation between data.

Table 4

Coefficients in the model with rational predictors

\begin{tabular}{|c|c|c|c|c|c|c|c|c|}
\hline \multirow{2}{*}{\multicolumn{2}{|c|}{ Model }} & \multicolumn{2}{|c|}{$\begin{array}{l}\text { Unstandardized } \\
\text { Coefficients }\end{array}$} & \multirow{2}{*}{$\begin{array}{c}\text { Standardized } \\
\text { Coefficients }\end{array}$} & \multirow[b]{2}{*}{$\mathrm{T}$} & \multirow[b]{2}{*}{ Sig. } & \multicolumn{2}{|c|}{ Collinearity Statistics } \\
\hline & & B & Std. Error & & & & Tolerance & VIF \\
\hline \multirow[t]{6}{*}{1} & (Constant) & 5,312 & 1,920 & & 2,767 & ,009 & & \\
\hline & $\begin{array}{l}\text { Reducing dependence from suppliers as a } \\
\text { factor in FDI decision making }\end{array}$ &,- 043 &, 272 &,- 028 &,- 159 &, 874 &, 845 & 1,184 \\
\hline & $\begin{array}{l}\text { Acquiring new technology as a factor in FDI } \\
\text { decision making }\end{array}$ &,- 493 &, 327 &,- 279 & $-1,505$ & , 142 & ,786 & 1,272 \\
\hline & $\begin{array}{l}\text { Upgrade in value chain as a factor in FDI } \\
\text { decision making }\end{array}$ &,- 415 & ,383 &,- 200 & $-1,085$ & ,286 &, 795 & 1,258 \\
\hline & ROI as a factor in FDI decision making &, 171 & ,285 &, 120 & 600 &, 553 & ,677 & 1,476 \\
\hline & $\begin{array}{l}\text { Feasibility analysis done by third, reputable } \\
\text { party as a factor in FDI decision making }\end{array}$ & ,094 & 257 &, 069 &, 365 & ,718 & ,749 & 1,334 \\
\hline
\end{tabular}

From the Table 4, it is necessary to primarily check firstly VIF and Tolerance values. Tolerance level for all variables is higher than 0.10 and VIF values for all variables are lower than 10, indicating that there is no multi-collinearity problem. As results from table clearly show, none of the rational predictors is statistically significant in explaining the dependent variable, at 0.05 level of significance. As it was case in testing previous hypothesis, authors decide not to rigorously dismiss results of the analysis, for the same reasons and with identical objectives.

By looking at unstandardized B coefficients another regression model is formed, this one with rational factors in FDI decision making. The model is given below in the Eq. (2). The equation shows contribution of each predictor variable (factor involved in FDI decision making based on standard economic theory) to average annual amount that company invests in foreign markets. Only two out of five included factors actually is related to higher amount of investment. These are ROI and feasibility analysis done by third reputable party. Coefficient related to ROI is 0.171 and to feasibility analysis is 0.094. These coefficients are much lower than that associated with business instinct in decision making from the Equation 1. The remaining predictors from Eq. (2) have negative coefficients. In case that decision makers in companies rely on these, average amount of direct investment will be lower. Negative coefficients related to reducing dependence from suppliers, acquiring new technology, and upgrade in value chain, are considerably high with amounts of $0.043,0.493$ and 0.415 respectively.

Average Annual Amount Of DI by Company in last 3 years

$=5.132+(-0.043)$ (Reducingdependancefromsuppliers)

$+(-0.493)$ (Acquiringnewtechnology)

$+(-0.415)$ (Upgradeinvaluechain) $+0.171($ ROI $)$

+0.094 (Feasibilityanalysisdonebythird, reputableparty) 


\section{Discussion}

For purpose of analyzing data collected from executives of 44 foreign companies that invest directly in $\mathrm{B} \& \mathrm{H}$, descriptive statistics, correlation and regression analysis were used.

Under assumption that irrational factors (including business instinct, previous experience in industry, visibility of investment in local community, desire to cut off the competition, and desire to acquire reputable brand) are significant in making decisions regarding FDI as opposed to rational factors (such as return on investment and profit margins), authors tested their predictive power of average annual amount of investment made directly in B\&H. Regression analysis showed that these factors were statistically insignificant in confidence interval of $95 \%$. However, authors decided to use results to see in what way reliance on these factors contributes to amount of DI made by company, for already stated motivations.

Instinct or feeling for business as a factor in making decisions causes companies to invest higher amounts in form of FDI. Having previous experience in industry makes companies likely to invest more in foreign markets, which relates to familiarity and feeling safer in certain business industry area. More visible investment opportunities in local markets are related to lower investments by companies from abroad. So, salience effect does not hold in case of making decisions related to FDI. One would expect that more salient investments will trigger higher amounts. However, it is possible that companies deliberately avoid opportunities that stand out in order to avoid being part of crowd or they have personal sources of information regarding business opportunities in B\&H. Desire to prevent their competitors to enter certain market and greed causes companies to invest higher amounts in foreign markets in form of direct investment. Also desire to acquire reputable brand makes companies ready to invest more into some markets. Obviously, these factors are not directly and explicitly related to motivation for acquiring higher returns on investment, which according to standard economic theory should be the main reason for making investment, especially when it comes to direct investments into foreign markets.

Under the second assumption that rational factors (including reducing dependence from suppliers, acquiring new technology, upgrade in value chain, ROI, feasibility analysis by third party ), authors tested their relation to and predictive power of average annual amount of investment made directly in $\mathrm{B} \& \mathrm{H}$. Regression analysis showed that these factors also were statistically insignificant in confidence interval of $95 \%$. As in the case of previous model authors decided to use results to see in what way reliance on these factors contributes to amount of FDI made by companies, for the identical motivations.

ROI and feasibility analysis contribute to higher amount of investments by foreign companies in B\&H. However, coefficients from model related to these two factors is far lower than coefficient related to business instinct. Therefore, companies whose decision makers rely on instinct actually invest higher amounts than companies whose decision makers rely on rational factors such as ROI and feasibility analysis. On the other side, three rational factors associated with higher profit margins (reducing dependence from suppliers, acquiring new technology, and upgrading value chain) result in lower amounts invested in $\mathrm{B} \& \mathrm{H}$ by foreign companies. Apparently, rational investors do not invest much to B\&H. On the other side these results imply that reliance on irrational factors (e.g. instinct in business) fosters investments and consequently economic growth along with appreciation for rational factors (e.g. ROI). When looking at all predictors from both models and their respective coefficients, it is apparent that the highest coefficient is related to business instinct as factor in FDI related decision making. Even though all coefficients were followed with high p-values (higher than 0.05 significance level), out of all predictors which are in positive relationship with dependent variable (annual amount of FDI to $\mathrm{B} \& \mathrm{H}), \mathrm{p}$-value related to this predictor is the lowest one. 


\section{Conclusion}

Behavioral economics combines psychological findings with economic ones with aim to apprehend and incorporate the true human characteristics into economic models, to look at how people actually behave and not how they should behave according to some previously set models. FDI is traditionally viewed in the frame of those previously set model which predict that economic agents are completely rational and act as conscious utility maximizers.

Analysis of survey amongst foreign companies' decision makers present in B\&H showed that higher investment amounts on yearly basis are associated with business instinct than with return on investment or recommendations of third party who prepares feasibility analysis.

However, analysis did not provide satisfactory results. Significance values associated with factors were high. Therefore, factors were statistically insignificant. Regardless of this, authors decided to comment on influence they have on amount of FDI inflow to B\&H. Main reasoning for such decision is very small sample size (44 responses) which could not provide very confident results.

Through the review of literature and survey amongst foreign investors in $\mathrm{B} \& \mathrm{H}$ it can be seen that field of behavioral economics has a lot to offer in understanding FDI decisions. It would be especially interesting to address the issue of emotions in making decisions related to FDI.

\section{References}

Aharoni, Y. (1966). The Foreign Investment Decision Process. Harvard University Press, Cambridge. Aharoni, Y. (1999). The Foreign Investment Decision Process. In The Internationalization of the Firm. Cengage Learning EMEA.

Ariely, D. (2008). Predictably Irrational. New York, USA: HarperCollins.

Baker, H. K., \& Nofsinger, J. R. (2002). Psychological biases of investors. Financial Services Review, 11(2), 97.

Barber, B. M., \& Odean, T. (2001). The internet and the investor. The Journal of Economic Perspectives, 15(1), 41-54.

Barberis, N., \& Thaler, R. (2003a). Chapter 18 A survey of behavioral finance. In M. H. and R. M. S. G.M. Constantinides (Ed.), Handbook of the Economics of Finance (Vol. Volume 1, Part B, pp. 1053-1128). Barberis, N., \& Thaler, R. (2003b). Chapter 18 A survey of behavioral finance. In M. H. and R. M. S. G.M. Constantinides (Ed.), Handbook of the Economics of Finance (Vol. Volume 1, Part B, pp. 1053-1128).

Bechara, A., Damasio, H., Tranel, D., \& Damasio, A. (1997). Deciding advantageously before knowing the advantageous strategy. Science, 275, 1293-1295.

Bentham, J. (1781). An Introduction to the Principles of Morals and Legislation. Kitchener: Batoche Books.

Bernheim, D. B. (2009). The psychology and neurobiology of judgement and decision making: What's in it for Economists? In Neuroeconomics: Decision Making and the Brain (1st ed., pp. 115-125). U.K.: Academic Press.

Buckley, P. J., \& Casson, M. C. (1976). The future of the multinational enterprise. Homes \& Meier: London.

Cushman, D. O. (1985). Real exchange rate risk, expectations and the level of direct investment. Review of Economics and Statistics, 67(2), 297-308.

Damasio, A. (1994). Descartes' Error: Emotion, Reason, and the Human Brain. New York: Putnam.

Daniel, K., Hirshleifer, D., \& Teoh, S. H. (2002). Investor psychology in capital markets: evidence and policy implications. Journal of Monetary Economics, 49(1), 139-209. http://doi.org/10.1016/S0304-3932(01)00091-5

Deffains, B., \& Ferrey, S. (2007). Théorie du droit et analyse économique. Droit, 45, 223-255. 
Denisia, V. (2010). Foreign direct investment theories: An overview of the main FDI theories. Academy of Economic Studies, 2(2), 104-110.

Dunning, J. (1988). The eclectic paradigm of international production: A restatement and some possible extensions. Journal of International Business, 19(1), 1-31.

Easterwood, J. C., \& Nutt, S. R. (1999). Inefficiency in analysts' earnings forecasts: systematic misreaction or systematic optimism? Journal of Finance, 54, 1777-1797.

Finucane, M. L., Alhakami, A., Slovic, P., \& Johnosn, S. M. (2000). The affect heuristic in judgements of risks and benefits. Journal of Behavioral Decision Making, 13, 1-17.

FIPA. (2014, February 2). FDI Position and Performance. Retrieved July 31, 2014, from http://www.fipa.gov.ba/informacije/statistike/investicije/default.aspx?id=180\&langTag=en-US

Hadžić, Z. (2015). Intuition in decision making: Comparison of middle-eastern and European decision making styles (Master Thesis). International Burch University, Sarajevo, B\&H.

Heiner, R. A. (1983). The origin of predictable behavior. American Economic Review, 73(4), 560-595.

Hosseini, H. (1994). Foreign direct investment. Humanmics, 10(1).

Hosseini, H. (2005). An economic theory of FDI: A behavioral economics and historical approach. The Journal of Socio-Economics, 34(4), 528-541. http://doi.org/10.1016/j.socec.2005.07.001

Hymer, S. (1976). The international operations of nation firms: A study of foreign direct investment. MLT Press, Cambridge.

Ilgün, E., \& Coşkun, A. (2009). Foreign direct investment in Bosnia and Herzegovina: Banking sector example. Alatoo Academic Studies, 4(2), 49-67.

Jarboui, S., \& Boujelbene, Y. (2012). The behavioral approach and the rationality of economic decisions: Application to banks managers. In M. Nejati \& M. Nejati, Global Business and Management Research : An International Journal Vol. 4, No. 2 (pp. 205-219). Universal-Publishers.

Johanson, J., \& Vahlne, J.-E. (1977). The internationalization process of the firm-A model of knowledge development and increasing foreign market commitments. Journal of International Business Studies, 8(1), 23-32.

Kahneman, D. (2011a). Thinking, Fast and Slow (First). New York: Farrar, Straus, and Giroux.

Kahneman, D. (2011b). Thinking, fast and slow (1st ed.). New York U.S.: Farrar, Straus, and Giroux.

Kahneman, D., Knetsch, J. L., \& Thaler, R. (1991). Anomalies: The endowment effect, loss aversion, and status Quo Bias. The Journal of Economic Perspectives, 5(1), 193-206.

Kahneman, D., \& Riepe, M. W. (1998). Aspects of investor psychology. The Journal of Portfolio Management, 24(4), 52-65. http://doi.org/10.3905/jpm.1998.409643

Kahneman, D., \& Tversky, A. (1979). Prospect theory: An analysis of decision under risk. Econometrica, 47(2), 263-292.

Kaplan, T., Luski, I., \& Wettstein, D. (2003). Government policy toward multinational corporations. Economics Bulletin, 6(3), 1-8.

Katona, G. (1975). Psychological economics (Vol. x). Oxford, England: Elsevier.

Keynes, J. M. (1973). The general theory of employment, Interest and Money. MacMilan, New York.

Kindleberger, C. P. (1969). American business abroad. The International Executive, 11(2), 11-12. http://doi.org/10.1002/tie.5060110207

Koppl, R. (1991). Animal spirits. Journal of Economic Perspectives, 5(3), 203-210.

Laar, M. van de, \& Neubourg, C. de. (2006). Emotions and foreign direct investment: A theorethical and empirical exploration. Management International Review, 46(2), 207-233.

Lucey, B. M., \& Dowling, M. (2005). The role of feelings in investor decision-making. Journal of Economic Surveys, 19(2), 211-237. http://doi.org/10.1111/j.0950-0804.2005.00245.x

Malcolm, N. (2002). Bosnia: A Short History. London U.K.: Pan Books, Pan Macmillian Ltd.

Markusen, J. R. (1995). The boundaries of multinational enterprises and the theory of international trade. The Journal of Economic Perspectives, 9(2), 169-189.

Moffett, M. H., Stonehill, A. I., \& Eiteman, D. K. (2009). Fundamentals of Multinational Finance (3rd ed.). Pearson Prentice Hall.

Mundell, R. A. (1957). International trade and factor mobility. The American Economic Review, 47(3), 321-335. 
Petricević, O., \& Danis, W. M. (2007). Bosnia and Herzegovina: Navigating a turbulent business environment. Thunderbird International Business Review, 49(4), 417-443. http://doi.org/10.1002/tie.20152

Pham, M. T., Lee, L., \& Stephen, A. T. (2012). Feeling the future: The emotional oracle effect. Journal of Consumer Research, 39(3), 461-477. http://doi.org/10.1086/663823

Pinheiro-Alves, R. (2008). Behavioural influences in Portuguese foreign direct investment (Phd Thesis). University of Bath, Economics and International Development Dept, U.K.

Rabin, M. (1998). Psychology and economics. Journal of Economic Literature, 36(1), 11-46.

Riley, G. (2012, September 23). Keynesian Economics. Retrieved February 2, 2014, from http://tutor2u.net/economics/revision-notes/as-macro-keynesian-economics.html

Rosenboim, M., Luski, I., \& Shavit, T. (2008). Behavioral approaches to optimal FDI incentives. Managerial and Decision Economics, 29, 601-607. http://doi.org/10.1002/mde.1435

Santander Trade Portal. (2014, July). Foreign investment in Bosnia and Herzegovina Santandertrade.com. Retrieved July 31, 2014, from https://en.santandertrade.com/establishoverseas/bosnia-and-herzegovina/investing

Schwartz, H. (2010). Does Akerlof and Shiller's Animal Spirits provide a helpful new approach for macroeconomics? The Journal of Socio-Economics, 39(2), 150-154. http://doi.org/10.1016/j.socec.2010.02.018

Serin, V., Caliskan, A., \& Karaahmet, G. (2008). Economic Liberalization and Foreign Direct Investment in Southeastern Europe. Proceedings of International Symposium on International Capital Flow and Emerging Markets,24-27 April 2008 Balikesir, 305-313.

Sewell, R. (2011). Psychology of Successful Investing. U.K.: University of Cambridge.

Shiller, R. J. (2000). Irrational Exuberance. Princeton, New Yersey: Princeton University Press.

Shiller, R. J. (2003). From efficient markets theory to behavioral finance. The Journal of Economic Perspectives, 17(1), 83-104.

Shull, D. (2013, April). Trading Psych 101 - Business Insider. Retrieved February 22, 2014, from http://www.businessinsider.com/trading-psych-101-2013-

4 utm source $=$ feedburner\&utm medium $=$ feed \&utm campaign $=$ Feed $\% 3 \mathrm{~A}+$ businessinsider $+\% 28$ Business + Insider $\% 29$

Shull, D. K. (2013). Improving your Market Movement Calls - The ReThink Group- The ReThink Group. $\quad$ Retrieved $\quad$ February 17, from http://www.marketmindgames.net/traderpsyches/improving-your-market-movement-calls/

Škuflić, L., \& Botrić, V. (2006). Foreign direct investment in southeast European countries: The role of the service sector. Eastern European Economics, 44(5), 72-90. http://doi.org/10.2753/EEE00128775440503

Slovic, P., Finucane, M., Peters, E., \& MacGregor, D. G. (2002). The affect heuristic. In T. Gilovich, D. Griffin, \& D. Kahneman, Heuristics and Biases: The Psychology of Intuitive Judgment (pp. 397420). New York: Cambridge University Press.

Taylor, C. T. (2000). The impact of host country government policy on US multinational investment decisions. World Economy, 23(5), 635-647. http://doi.org/10.1111/1467-9701.00294

Thaler, R. (Ed. . (1993). Advances in behavioral finance. New Yorkl: Russell Sage Foundation.

Vernon, R. (1966). International investment and international trade in the product cycle. Quarterly Journal of Economics, 80, 190-207.

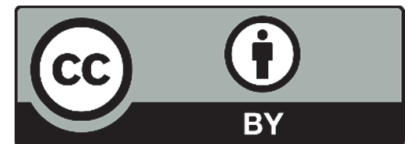

(C) 2016 by the authors; licensee Growing Science, Canada. This is an open access article distributed under the terms and conditions of the Creative Commons Attribution (CC-BY) license (http://creativecommons.org/licenses/by/4.0/). 